\title{
Penerapan Model Pembelajaran Kooperatif Tipe STAD Dalam Meningkatkan Pemahaman Konsep Matematika Materi Himpunan Pada Siswa Kelas VII 4 SMP Negeri 13 Tahun 2016
}

\author{
Ernawilis* \\ * SMP Negeri 13 Pekanbaru
}

\begin{tabular}{l} 
INFO ARTIKEL \\
Riwayat Artikel: \\
Diterima: 6 Maret 2018 \\
Disetujui: 10 Juni 2018 \\
\hline
\end{tabular}

\section{Kata kunci:}

Model Pembelajaran Kooperatif STAD

Pemahaman Konsep Matematika Materi Himpunan

\author{
Alamat Korespondensi: \\ Ernawilis, \\ SMP Negeri 13 Pekanbaru \\ Jl. Ronggowarsito I No. 15 Pekanbaru \\ E-mail: ernawilis@gmail.com
}

\begin{abstract}
ABSTRAK
Abstract: Background of this research is about the low interest in following the process of classroom learning spread by the author to 39 students in class VII 4 SMP Negeri 13 Pekanbaru. Learning that has been too monotonous adds to the cause of the low interest in learning which affects the poor results of learning, especially in learning mathematics. Therefore, there needs to be a new trobosan in order to increase students' learning interest in following the learning. This research was conducted in Pekanbaru City precisely on the students of class VII 4 SMP Negeri 13 Pekanbaru in the Lesson 2016. The purpose of this research is to know by using STAD type cooperative learning model can improve the understanding of basic concepts of mathematics discussion of the students of class VII 4 SMP Negeri 13 Pekanbaru Year 2016. This research consists of 2 cycles, while every cycle I is done in 4 meetings and on the second cycle conducted 2 meetings. Each cycle consists of steps Planning / preparation of action, implementation of action, observation and reflection. After the results of cycle 1 are obtained and have been reflected, further improvement is made to proceed to the next cycle if necessary. The result of this research is the increasing of the students ability to master the learning material that is marked with the value of cycle I, the number of students who reach KKM as many as 24 students or $72.73 \%$, on the second cycle as many as 28 students or $87.5 \%$. The conclusion of this class action research is in general could be happened saturation of student in follow lesson given by teacher so that need new breakthrough so that student become willing and interested in follow learning. By using STAD type cooperative learning method impact on result of research every cycle which increase significantly.
\end{abstract}

\section{LATAR BELAKANG}

Pembelajaran Kooperatif merupakan sebuah startegi pengajaran yang melibatkan siswa bekerja secara berkolaborasi untuk mencapai tujuan bersama. Selanjutnya Anita Lie $(2002 ; 12)$ menyatakan bahwa pembelajaran Kooperatif atau pembelajaran bergotong royong adalah sistem pengajaran yang memberikan kesempatan kepada anak didik untuk bekerja sama dengan sesama siswa dalam tugas-tugas yang terstruktur. Pengetahuan tentang pembelajaran kooperatif dikemukakan dan dikembangkan untuk siswa, sementara itu guru hanya menciptakan kondisi dan situasi yang memungkinkan siswa untuk membentuk makna dari bahan-bahan yang dipelajari. Siswa dianjurkan untuk membangun pengetahuan secara aktif sebab belajar adalah suatu 
10 Instructional Development Journal (IDJ), Vol. 1, No. 1, Juni 2018, Hal.9-14

kegiatan yang dilakukan siswa, bukan sesuatu yang dilakukan terhadap siswa. Jadi siswa tidak menerima pengetahuan dari guru atau kurikulum secara pasif. Guru perlu berusaha mengembangkan kompetensi dan kemampuan siswa, berdasarkan asumsi bahwa usaha pendidikan bisa meningkatkan kemampuan mereka.

Pembelajaran kooperatif merupakan strategi yang menempatkan siswa belajar dalam kelompok yang beranggotakan 4-5 siswa dengan tingkat kemampuan atau jenis kelamin atau latar belakang yang berbeda. Model Pembelajaran Koperatif tipe STAD merupakan pendekatan Cooperative Learning yang menekankan pada aktivitas dan interaksi diantara siswa untuk saling memotivasi dan saling membantu dalam menguasai materi pelajaran guna mencapai prestasi yang maksimal. Guru yang menggunakan STAD mengajukan informasi akademik baru kepada siswa setiap minggu mengunakan presentasi Verbal atau teks. STAD telah digunakan dalam berbagai mata pelajaran, salah satunya adalah pelajaran matematika. Gagasan utama dari STAD adalah untuk meningkatkan pemahaman konsep siswa supaya dapat saling mendukung dan membantu satu sama lain dalam menguasai materi yang diajarkan oleh guru. Jika para siswa ingin agar timnya mendapatkan penghargaan tim, mereka harus membantu teman satu timnya untuk mempelajari materi. Mereka harus mendukung teman satu timnya untuk bisa melakukan yang terbaik, menunjukkan bahwa belajar itu penting, berharga dan menyenangkan. Para siswa bekerja sama setelah guru menyampaikan materi pelajaran. Mereka boleh mendiskusikan dari pendekatan penyelesaian masalah, atau mereka juga boleh saling memberikan kuis mengenai objek yang mereka pelajari. Mereka saling bekerja sama dengan teman satu timnya, menilai kekuatan dan kelemahan untuk membantu mereka berhasil dalam kuis.

Kemudian melihat besarnya potensi pengembangan kemampuan siswa dengan menggunakan metode tersebut penulis tertarik untuk membuat penelitian yang berjudul "Penerapan Model Pembelajaran Kooperatif Tipe STAD Dalam Meningkatkan Pemahaman Konsep Matematika Materi Himpunan Pada Siswa Kelas VII 4 SMP Negeri 13 Pekanbaru Tahun 2016".

\section{METODE}

Metode yang dilakukan dalam penelitian ini adalah metode Penelitian Tindakan Kelas (PTK). Penelitian tindakan kelas merupakan suatu pencermatan terhadap kegiatan belajar berupa sebuah tindakan, yang sengaja dimunculkan dan terjadi dalam sebuah kelas secara bersama. Tindakan tersebut diberikan oleh guru atau dengan arahan dari guru yang dilakukan oleh siswa. Kesalahan umum yang terdapat dalam penelitian tindakan guru adalah penonjolan tindakan yang dilakukannya sendiri, misalnya guru memberikan tugas kelompok kepada siswa. (Suharsimi Arikunto, 2010:3). Penelitian ini menekankan pada tindakan dilakukan oleh peserta didik di bawah bimbingan dan arahan guru.

Penelitian ini menggunakan model spiral yang dik embangkan oleh Kemmis dan Taggart. Dalam model ini terdapat empat tahapan yang harus dil akukan yaitu perencanaan, tinda kan, observasi, dan refleksi. Berikut bagan dari model spiral Kemmis dan Taggart yang diambil dari Rochiati Wiriaatmadja (2005: 66). Adapun rancangan penelitian tindakan yang akan dilaksanakan pada setiap siklusnya terdiri dari:

Perencanaan Tindakan

Kegiatan yang dilakukan pada tahap perencanaan tindakan ini meliputi: 1) Menyusun Rencana Pelaksanaan Pembelajaran (RPP); 2) Menyusun dan mempersiapkan lembar observasi mengenai pelaksanaan pembelajaran dan lembar angket respons siswa terhadap pelaksanaan pembelajaran matematika menggunakan model pembelajaran kooperatif tipe Student Teams Achievement Division (STAD); 3) Menyususn pedoman wawancara untuk siswa. Pedoman wawancara dibuat untuk mempermudah peneliti untuk mengetahui bagaimana respon siswa dan hambatan yang dirasakan siswa terhadap kegiatan pembelajaran; 4) Menyusun Lembar Kerja Siswa (LKS). LKS yang digunakan ini merupakan lembar kegiatan siswa untuk membantu proses pembelajaran yang dilengkapi dengan latihan soal-soal untuk siswa. LKS disusun oleh peneliti dengan pertimbangan dari dosen pembimbing dan guru yang mengampu pelajaran matematika kelas VII 4 SMP Negeri 13 Pekanbaru; 5) Mempersiapkan soal tes untuk siswa yaitu soal tes untuk akir siklus 1 dan siklus 2, serta soal kuis yang akan diberikan pada setiap akhir pembelajaran. 


\section{Pelaksanaan Tindakan}

Pada tahap ini, pembelajaran menggunakan model pembelajaran kooperatif tipe Student Teams Achievement Division (STAD) dilaksanakan. Pelaksanaan pembelajaran mengacu pada rencana yang telah disusun yaitu: 1) Persiapan materi dan penerapan siswa dalam kelompok yang terdiri dari 4-5 siswa. Siswa dikelompokkan menurut prosedur STAD; 2) Penyajian materi pelajaran, ditekankan pada hal-hal berikut: a) Pendahuluan (Guru menyampaikan tujuan pembelajaran, memberikan apersepsi serta memotvasi siswa agar berpartisipasi aktif dalam pembelajaran; b) Kegiatan Inti (Presentasi Kelas, ini merupakan pengajaran langsung seperti yang sering kali dilakukan atau didiskusikan pelajaran yang dipimpin oleh guru; Kerja Kelompok, Siswa berdiskusi dalam kelompok menyelesaikan soal LKS, dalam diskusi ini siswa diharapkan untuk saling membantu apabila teman satu kelompoknya ada yang belum menguasai materi. Dalam hal ini guru berfungsi sebagai fasilitator dan mulai memberi penjelasan apabila dalam suatu kelompok tidak ada satupun siswa yang dapat menjelaskan materi tersebut. Setelah LKS selesai dikerjakan maka salah satu anggota kelompok dipersilahkan untuk menuliskan hasil diskusi kelompoknya di papan tulis, siswa dengan jawaban berbeda akan mempresentasikan hasil diskusi kelompoknya di depan kelas. Selanjutnya siswa menarik kesimpulan dari materi yang telah diperoleh dalam diskusi dan guru menguatkan hasil kesimpulan yang diperoleh siswa; Kuis Individu, Siswa mengerjakan kuis individu, kuis ini dilakukan selama 15 menit secara mandiri. Kuis ini bertujuan untuk menunjukkan apa yang telah siswa pelajari selama bekerja dalam kelompok); 3) Penutup, Guru memberikan penghargaan kepada kelompok yang berhasil mencapai rata-rata skor tertinggi. Pemberian penghargaan tiap kelompok ini dapat ditentukan berdasarkan skor kelompok yang didapat dengan menjumlah nilai rata-rata peningkatan anggota kelompoknya.Pemberian penghargaan berdasarkan skor kelompok diberikan pada pertemuan kedua dan selanjutnya, sedangkan pada pertemuan pertama penghargaan diberikan berdasarkan keaktifan saat berdiskusi dan keberhasilan dalam mempresentasikan hasil diskusi, karena pertemuan pertama belum bisa dihitung peningkatan skor individu.

Observasi

Observasi dilakukan dengan mengamati secara langsung bagaimana aktivitas siswa maupun guru selama proses belajar mengajar. Pada saat observasi dilaksanakan peneliti telah mempersiapkan lembar observasi, guna mengetahui keterlaksanaan pembelajaran dengan menggunakan model pembelajaran kooperatif tipe Student Team Achievement Divisions (STAD), dalam hal ini di dalam kelas. Setiap aktivitas yang terjadi selama proses belajar mengajar berlangsung diusahakan untuk dicatat seperti apa adanya agar diperoleh informasi lapangan yang sebenarnya.

Refleksi

Pada tahap refleksi ini, peneliti bersama-sama dengan guru mata pelajaran matematika mengadakan pertemuan guna melakukan evaluasi terhadap proses pembelajaran yang telah berlangsung. Refleksi dilakukan setelah akhir siklus. Diskusi tersebut bertujuan untuk mengevaluasi hasil tindakan yang telah dilakukan yaitu dengan cara melakukan penilaian terhadap proses yang terjadi, masalah yang muncul dan segala hal yang berkaitan dengan tindakan yang dilakukan. Setelah itu peneliti merumuskan tindakan berikutnya dan apabila berdasarkan refleksi perlu dilaksanakan pengulangan siklus maka dapat diulang lagi sampai dirasa pembelajaran telah optimal.

\section{HASIL DAN PEMBAHASAN}

Pembelajaran matematika melalui model kooperatif tipe STAD ini diawali dengan presentasi kelas oleh guru, yaitu menyampaikan materi dengan jelas dan singkat. Setelah presentasi guru, siswa berkelompok berdiskusi, bekerja sama, dan saling membantu satu sama lain dalam mengintegrasikan pengetahuanpengetahuan baru dengan pengetahuan yang telah dimilikinya. Kelompok diskusi yang digunakan dalam penelitian ini beranggotakan 4-5 orang siswa.Kelompok dibentuk berdasarkan hasil nilai tes awal.

Erman Suherman (2003: 202) menyatakan bahwa ukuran (besar kecilnya) kelompok akan berpengaruh pada kemampuan produktivitas kelompoknya. Ukuran kelompok yang ideal untuk cooperative learning adalah tiga sampai lima orang. Jika suatu kelompok hanya terdiri atas dua orang, maka interaksi antar anggota kelompok 
12 Instructional Development Journal (IDJ), Vol. 1, No. 1, Juni 2018, Hal.9-14

akan sangat terbatas dan kelompok itu tidak dapat melakukan diskusi jika satu anggotanya absen. Sebaliknya, jika ukuran kelompok itu terlalu besar maka akan menjadi sangat sulit bagi kelompok itu berfungsi secara efektif. Siswa-siswa yang lebih aktif dalam pembelajaran akan cenderung menguasai dan siswa-siswa yang hanya pendiam akan cenderung menerima saja apa yang diberikan guru. Dalam kelompok yang sangat besar, sulit bagi setiap individu untuk menyampaikan pendapat dan mengkoordinasinya. Selain itu, guru selalu memonitor kinerja siswa dalam kelompok. Guru melakukan hal tersebut agar dapat membantu siswa yang mengalami kesulitan dalam menghubungkan konsep-konsep yang mereka pelajari dengan pengalaman yang mereka miliki. Setelah siswa selesai mendiskusikan LKS yang diberikan, maka kegiatan selanjutnya adalah pembahasan atau presentasi kelas oleh siswa. Siswa menuliskan hasil diskusi kelompok mereka pada papan tulis, dengan menuliskan hasil diskusi kelompok di papan tulis ini maka siswa dapat mengetahui benar atau salah jawaban hasil diskusi mereka, hal ini akan memberi pengetahuan yang lebih kepada siswa.

Pada saat pelaksanaan pembahasan, guru selalu menampung alternatif jawaban yang berbeda yang diperoleh tiap kelompok. Guru juga memerintahkan siswa untuk mencatat hasil diskusi kelas mereka jika jawaban yang diperoleh berbeda dengan jawaban siswa sebelumnya. Saat pembahasan terhadap jawaban dalam presentasi, guru memerintahkan kepada siswa lain untuk mencermati hasil jawaban yang ditulis di papan tulis. Setelah pembahasan selesai, guru mengajak para siswa untuk menyimpulkan materi yang telah disampaikan.Hal ini melatih siswa untuk menganalisis dan menarik kesimpulan dari berbagai pernyataan.Guru juga menghimbau untuk setiap siswa untuk mencatat kesimpulan materi yang disimpulkan oleh guru bersama siswa. Dari hasil observasi pelaksanaan pembelajaran yang dilakukan, proses pembelajaran dapat berjalan dengan baik.Walaupun ada beberapa yang tidak sesuai dengan rencana, karena tidak semua soal pada LKS dapat dipresentasikan oleh siswa seperti yang terjadi pada siklus pertama. Selama kegiatan pembelajaran, terlihat aktivitas siswa lebih dominan dibandingkan dengan guru. Sehingga, proses pembelajaran tidak lagi merupakan pembelajaran yang terpusat pada guru, tetapi siswa menjadi lebih mandiri dalam proses pembelajaran. Belajar dengan cara diskusi kelompok, dimana kelompok terdiri dari anggota dengan tingkat akademis yang heterogen akan memberi kesempatan kepada siswa untuk bekerjasama. Biasanya siswa yang lebih pandai menjadi tempat bertanya teman yang lain.

Berdasar nilai kuis rata-rata nilai siswa terjadi peningkatan dari siklus I ke siklus II. Dalam siklus I, kuis I rata-rata nilai siswa 73,33 dan kuis II rata-rata nilai siswa 74,5, sedangkan untuk siklus II kuis III rata-rata nilai siswa 89,38 dan kuis IV rata-rata nilai siswa 88,79. Selain itu, dalam lembar rangkuman tim dapat terlihat bahwa ada kelompok yang selalu mendapatkan predikat sebagai tim super seperti kelompok A dan C walaupun masih ada kelompok yang mendapatkan predikat tim sangat baik dan tim baik. Berdasarkan nilai tes akhir siklus, terjadi peningkatan dari siklus I ke siklus II. Ketuntasan belajar siswa untuk siklus I dan siklus II juga telah melebihi batas ketuntasan belajar minimal siswa kelas VII, yakni sebesar 70\% dari keseluruhan jumlah siswa dalam satu kelas. Berdasarkan tes yang dikerjakan siswa secara individu, nampak pula adanya peningkatan pada masingmasing indikator pemahaman konsep matematika siswa dari siklus I ke siklus II. Penghitungan didasarkan atas banyaknya siswa yang menjawab benar untuk setiap butir soal yang menunjukkan masing-masing indikator pemahaman konsep matematika.

Menurut Slavin (2008: 144), fungsi utama dalam tim adalah memastikan bahwa semua anggota tim benarbenar belajar, dan lebih khususnya lagi, adalah untuk mempersiapkan anggotanya untuk mengerjakan kuis dengan baik. Setelah guru menyampaikan materinya, tim berkumpul untuk mempelajari lembar kegiatan atau materi. Yang paling sering terjadi, pembelajaran itu melibatkan pembahasan permasalahan bersama, membandingkan jawaban, dan mengoreksi tiap kesalahan pemahaman apabila anggota tim ada yang membuat kesalahan. Menurut Nana Sujana (2004: 79-80), diskusi pada dasarnya adalah tukar menukar informasi, pendapat dan pengalaman dengan maksud untuk mendapat pengertian bersama.Adanya kerjasama dalam kelompok menandakan bahwa semakin banyak ide-ide yang muncul dari setiap siswa. Banyaknya ide-ide yang muncul ini tentunya akan semakin memperkaya pengetahuan dan pemahaman siswa. Kemudian, karena tim itulah dapat meningkatkan pemahaman konsep siswa dan akhirnya mencapai prestasi yang diinginkan. Dengan demikian, penerapan pembelajaran matematika dengan menggunakan model pembelajaran kooperatif tipe 
Student TeamAchievement Divisions (STAD) pada siswa di SMP Negeri 13 Pekanbaru khususnya kelas VII 4, dapat meningkatkan pemahaman konsep matematika siswa.

\section{SIMPULAN DAN SARAN}

\section{Simpulan}

Dari hasil penelitian yang dilakukan dan pembahasan yang telah diuraikan, maka diperoleh kesimpulan bahwa sebagai berikut: 1) Pelaksanaan pembelajaran matematika dengan model pembelajaran kooperatif tipe Student Team Achievement Divisions (STAD) untuk meningkatkan pemahaman konsep matematika adalah sebagai berikut: a) Guru mengelompokkan siswa menjadi 8 kelompok menurut prosedur STAD, tujuh kelompok beranggotakan 4-5 orang siswa; b) Guru menyampaikan presentasi kelas dengan memberikan materi pelajaran secara singkat; c) Siswa berdiskusi dalam kelompok untuk menyelesaikan LKS; d) Siswa menuliskan hasil diskusi kelompok mereka di papan tulis; e) Guru bersama siswa melakukan pembahasan alternatif jawaban yang digunakan siswa dalam menjawab pertanyaan; f) Guru dan siswa menyimpulkan masalah yang telah siswa diskusikan dalam kelompoknya maupun hasil dari presentasi kelas; g) Dilaksanakan kuis sebanyak 4 kali, kuis dikerjakan secara individu; h) Menentukan poin kemajuan individu dengan membandingkan skor kuis baru yang diperoleh dengan skor kuis pada pertemuan sebelumnya; dan i) Guru memberikan penghargaan kepada kelompok-kelompok yang berprestasi; 2) Pemahaman konsep matematika siswa kelas VII 4 di SMP Negeri 13 Pekanbaru mengalami peningkatan setelah dilaksanakan pembelajaran matematika dengan model pembelajaran kooperatif tipe Student Team Achievement Divisions (STAD). Hal ini ditandai dengan nilai rata-ratasiswa kelas VII 4 meningkat dari tes kemampuan awal sebesar 50,67 ke siklus I sebesar 71,76 dansiklus II sebesar 75,56. Selain itu dapatd iketahui pula bahwa ketuntasan belajar siswa telah memenuhi batas kriteria kelulusan minimal. Ketuntasan belajar siswa pada siklus I sebesar 72,73\% dan pada siklus II meningkat menjadi 87,5\%.

\section{Saran}

Berdasarkan hasil penelitian yang dilakukan dan pembahasan, selama pelaksanaaan penelitian dengan model pembelajaran kooperatif tipe Student Achievement Divisions (STAD) yang telah dilakukan, peneliti memberikan masukan atau saran yang perlu dipertimbangkan oleh berbagai pihak berkaitan dengan penerapan model pembelajaran STAD sebagai upaya meningkatkan pemahaman konsep matematika pada siswa kelas VII SMP Negeri 13 Pekanbaru, yaitu: 1) Kepada pihak sekolah, diharapkan agar metode belajar ini dapat menjadi metode alternatif yang digunakan di SMP Negeri 13 Pekanbaru dan dapat dilaksanakan secara bergantian dengan model pembelajaran yang lain. Karena penerapan model pembelajaran kooperatif tipe Student Achievement Divisions (STAD) dapat meningkatkan pemahaman konsep matematika siswa; 2) Kepada peneliti lain dapat melakukan penelitian lebih lanjut menggunakan model pembelajaran STAD dengan mencakup aspek selain pemahaman konsep dan mengaplikasikannya pada materi pembelajaran yang berbeda atau pada mata pelajaran selain matematika.

\section{DAFTAR RUJUKAN}

Anas Sudijono. 1996. Pengantar Evaluasi Pendidikan. Jakarta : PT Raja Grafindo Persada

Anita Lie. 2007. Cooperative Learning (Mempraktikan Cooperative Learning di Ruang-ruang Kelas). Jakarta: Grasindo Djemari Mardapi. 2008. Teknik Penyusunan Instrumen Tes dan Nontes. Jogjakarta: Mitra Cendekia Press.

Erman Suherman. 2003. Strategi Pengajaran Matematika Kontemporer. Bandung: JICA

Herman Hudojo. 2003. Pengembangan Kurikulum dan Pembelajaran Matematika. Malang: Universitas Negeri Malang

Ibrahim, M. et. al. 2000. Pembelajaran Kooperatif. Surabaya: Universitas Negeri Surabaya Press.

Kunandar 2008. Langkah Mudah Penelitian Tindakan Kelas sebagai Pengembangan Profesi Guru. Jakarta : Raja Grasindo Persada 
14 Instructional Development Journal (IDJ), Vol. 1, No. 1, Juni 2018, Hal.9-14

Nana Sudjana. 2002. Penilaian Hasil Proses Belajar Mengajar. Bandung : Remaja Rodaskarya

Oemar Hamalik. 2005. Proses Belajar Mengajar. Jakarta : Bumi Aksara

Robert E. Slavin. 2008. COOPERATIVE LEARNING Teori Riset dan Praktik. (terjemahan). Bandung: Nusa Media. Buku asli diterbitkan (London : Allymand Bacon, 2005).

Rochiati Wiriaatmadja. 2009. Metode Penelitian Tindakan Kelas. Bandung : Remaja Rosdakarya.

Slameto. 1995. Belajar dan Faktor-Faktor yang Mempengaruhianya. Jakarta : Rineka Cipta

Slavin, R.E. 2009. Cooperative Learning. Boston: Allyn and Bacon Inc.

Suharsimi Arikunto. 1986. Pengelolaan Kelas dan Siswa Sebuah Pendekatan Evaluatif. Jakarta : Rajawali

Suharsimi Arikunto, Suhardjono, \&Supardi. 2006. Penelitian Tindakan Kelas. Jakarta: Bumi Aksara

Sujono. 1988. Pengajaran Matematika untuk Sekolah Menengah. Jakarta : Depdiknas

Syaiful Sagala. 2009. Konsep dan Makna Pembelajaran Untuk Membantu Memecahkan Problematika Belajar dan Mengajar. Banduang : Alfabeta

Winkel. 2004. Psikologi Pengajaran. Yogyakarta: Media Abadi 